\title{
Preparation of Activated Carbons from Mongolian Lignite and Sub-Bituminous Coal by a Physical Method
}

\author{
Uugantsetseg Gombojav, Irekhbayar Jambal, Enkhsaruul Byambajav \\ Laboratory of Clean Energy Technology Development, Department of Chemistry, National University of Mongolia, \\ Ulaanbaatar, Mongolia \\ Email: enkhsaruul_b@num.edu.mn
}

How to cite this paper: Gombojav, U., Jambal, I. and Byambajav, E. (2020) Preparation of Activated Carbons from Mongolian Lignite and Sub-Bituminous Coal by a Physical Method Journal of Minerals and Materials Characterization and Engineering, 8, 97-106.

https://doi.org/10.4236/jmmce.2020.83007

Received: March 10, 2020

Accepted: April 18, 2020

Published: April 21, 2020

Copyright () 2020 by author(s) and Scientific Research Publishing Inc. This work is licensed under the Creative Commons Attribution International License (CC BY 4.0).

http://creativecommons.org/licenses/by/4.0/

\begin{abstract}
Preparation of activated carbons by a physical activation technique is performed using the methods of coal pyrolysis and gasification at different temperatures. As increasing pyrolysis temperature from $520^{\circ} \mathrm{C}$ to $700^{\circ} \mathrm{C}$, the yield of activated carbons from the Khuut $(\mathrm{KH})$ sub-bituminous coal is lowered, and amount of micropores increases gradually; however there is no development of mesopores by the $\mathrm{KH}$ coal pyrolysis. When the $\mathrm{KH}$ coal has a small loss during its physical activation due to difficulty and inactivity of its macrostructure decomposition, the smaller porosity is developed in the resulting carbons. The Aduunchuluun (AD) lignite is activated by pyrolysis and gasification at the highest temperature of $700^{\circ} \mathrm{C}$ in the present study. It is identified that the gasification of $\mathrm{AD}$ lignite develops well a porous structure with the highest surface area of $522 \mathrm{~m}^{2} / \mathrm{g}$ which is three times larger than that (155 $\mathrm{m}^{2} / \mathrm{g}$ ) of the activated carbon produced by pyrolysis of the same lignite. The IR and SEM analysis confirm a significant difference in chemical and structural changes between the $\mathrm{AD}, \mathrm{KH}$ raw coals and corresponding carbon samples in the physical activation processes.
\end{abstract}

\section{Keywords}

Coal-Based Activated Carbon, Porous Structure, Physical Activation, Micropores, Mesopores

\section{Introduction}

Activated carbon has recently received much attention as adsorbent material because of its adsorptive capacity and as a catalyst support for several chemical processes, since it has high surface area, good resistance to coke deposition, rela- 
tively ready control of pore structures [1]-[15]. Consequently, the need of activated carbon is increasing continuously. However, activated carbon is high-priced that restrained its bulk-scale production. Due to cost effective concept, coal is considered as a promising resource for adsorbent preparation processes. Generally, activated carbons can be produced by physical and chemical activation processes. Every method has its own advantages and disadvantages. Yong Zou and Bu-Xing Han reported that three Chinese coals are proven to be suitable raw materials for activated carbons prepared by chemical activation, and anthracite coal gives the high-surface-area activated carbon [2]. Nakamura and Fujimoto have physically prepared the activated carbon using $\mathrm{CO}_{2}$ gasification of an Australian Yallourn coal, and its porosity is higher compared to that of commercial activated carbon [3]. Also $\mathrm{H}$. Teng et al. have demonstrated the phosphoric acid is a suitable activating agent for the preparation of high porosity carbon from bituminous coal [4].

Mongolia has a rich source of coal, the amount of which is accounted geologically by 173 billion tons. Type of most coal resource is an energy and non-coking coal. Therefore, it is economically desirable to prepare valuable adsorbent materials from the non-coking coal besides its energy application. In the present study, we aim to determine a possibility to prepare activated carbons from Mongolian coals by their pyrolysis in inert atmosphere and also gasification with a steam. In order to make a clear effect of coal type, the samples of lignite and sub-bituminous coal are selected in this research. Due to sustainable and eco-friendly production concepts, the physical methods of pyrolysis and steam gasification without strong acid and alkaline usage are examined for the preparation of coal-based activated carbons from Aduunchuluun lignite and Khuut subbituminous coal, in this research work.

\section{Experimental Methods}

\subsection{Samples}

The Aduunchuluun lignite (coded as AD) deposit is located near to Choibalsan city of Dornod province, and its reserve is estimated at approximately 300 million tons. The sub-bituminous Khuut coal (coded as $\mathrm{KH}$ ) deposit is far of $26 \mathrm{~km}$ from Bayanjargalan village of Dognogovi province, and its reserve is similar to that of previous one. The coal samples are ground and sieved to produce batch with particle sizes of $0.074-0.15 \mathrm{~mm}$. Proximate and ultimate analysis of the coal samples are summarized in Table 1.

Table 1. Proximate and ultimate analysis of research raw materials.

\begin{tabular}{|c|c|c|c|c|c|c|c|c|}
\hline \multirow{2}{*}{$\begin{array}{l}\text { Coal } \\
\text { code }\end{array}$} & \multicolumn{4}{|c|}{ Proximate analysis, wt $\%$} & \multicolumn{4}{|c|}{ Ultimate analysis, wt\% (daf) } \\
\hline & $\mathrm{M}, \mathrm{wt} \%$ (a.r) & $\mathrm{A}, \mathrm{wt} \%(\mathrm{~d})$ & $\mathrm{V}, \mathrm{wt} \%(\mathrm{~d})$ & Q, ксаl/кg (daf) & $\mathrm{C}$ & $\mathrm{H}$ & $\mathrm{N}$ & $\mathrm{O}^{1)}$ \\
\hline $\mathrm{KH}$ & 13.1 & 16.7 & 43.4 & 4747 & 75.4 & 5.0 & 1.0 & 18.6 \\
\hline $\mathrm{AD}$ & 38.7 & 9.9 & 45.8 & 3203 & 66.0 & 4.1 & 0.8 & 29.5 \\
\hline
\end{tabular}

${ }^{1)}$ By difference. 


\subsection{Preparation of Activated Carbon from Coal Samples-Pyrolysis and Steam Gasification}

Preparation of activated carbons by physical activation technique is performed using two methods: pyrolysis and gasification. Pyrolysis of a coal sample is performed in a Fischer retort. $50 \mathrm{~g}$ of coal sample is heated at a rate of $17^{\circ} \mathrm{C} / \mathrm{min}$ up to temperature of $520^{\circ} \mathrm{C}, 600^{\circ} \mathrm{C}$ or $700^{\circ} \mathrm{C}$, and hold at that temperature for 30 minutes.

Activation by steam gasification is carried out in a stainless vertical fixed bed reactor. About $500 \mathrm{mg}$ of coal sample is first heated up with a heating rate of $25^{\circ} \mathrm{C} / \mathrm{min}$ to temperature of $700^{\circ} \mathrm{C}$ in a stream of argon inert gas, then hold for $10 \mathrm{~min}$ to remove preliminarily coal volatiles, and finally exposed to $50 \mathrm{vol} \%$ $\mathrm{H}_{2} \mathrm{O}$ in argon carrier gas to gasify in situ the resulting solid residue for development of porous structure in the carbon at the temperature of $700^{\circ} \mathrm{C}$ for $30 \mathrm{mi}$ nutes.

The obtained activated carbons are named as coal code with corresponding activation temperature as follows: $\mathrm{KH} 520^{\circ} \mathrm{C}-\mathrm{P}, \mathrm{KH} 600^{\circ} \mathrm{C}-\mathrm{P}, \mathrm{KH} 700^{\circ} \mathrm{C}-\mathrm{P}$, $\mathrm{AD} 700^{\circ} \mathrm{C}-\mathrm{P}$ and $\mathrm{KH} 520^{\circ} \mathrm{C}-\mathrm{G}, \mathrm{KH} 600^{\circ} \mathrm{C}-\mathrm{G}, \mathrm{KH} 700^{\circ} \mathrm{C}-\mathrm{G}, \mathrm{AD} 700^{\circ} \mathrm{C}-\mathrm{G}$. Figure 1 shows a total scheme of this research method.

\subsection{Characterization of Activated Carbons}

Methylene blue adsorption. Adsorption of activated carbon is tested in terms of methylene blue for determination of meso-sized pore formation [16]. Analysis procedure is followed through steps: $0.1 \mathrm{~g}$ of activated carbon sample is added to $5 \mathrm{ml}$ of the methylene blue test solution, then shake this solution until decoloring occurs. Addition of methylene blue test solution in $1 \mathrm{ml}$ portions is repeated till decoloring within five minutes. The entire volume of test solution decolorized by the activated carbon is calculated in every sample.

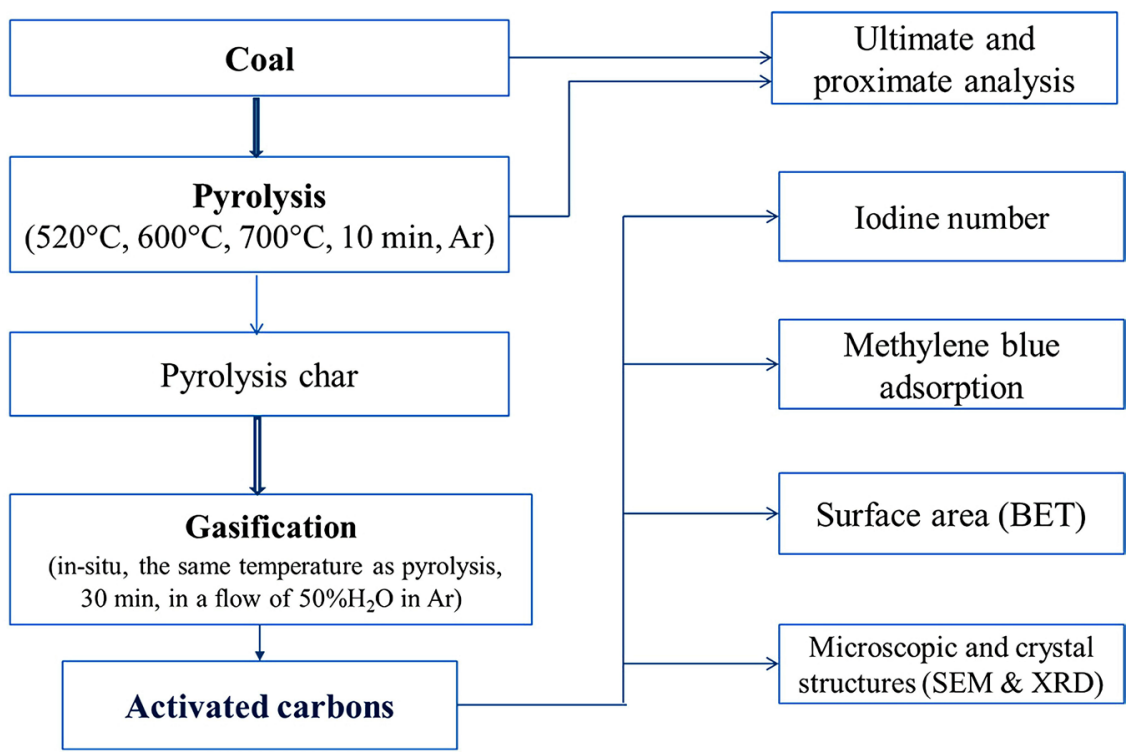

Figure 1. A total scheme of the research method. 
Iodine number determination. $50 \mathrm{ml}$ iodine solution with concentration of 0.1 $\mathrm{N}$ is added to $1 \mathrm{~g}$ of activated carbon sample. After 15-minute shaking, the solution is kept for 5 minutes to separate the phases of activated carbon and iodine solution. The $10 \mathrm{ml}$ iodine solution is titrated by $0.1 \mathrm{~N}$ solution of $\mathrm{Na}_{2} \mathrm{~S}_{2} \mathrm{O}_{3}$ in the presence of a starch indicator until disappearing the blue color. Iodine number is calculated as follows:

$$
X \%=\frac{\left(V_{0}-V_{1}\right) * 0.0127 * 100 * 50}{m * 10}
$$

$V_{1}$-consumed amount of $0.1 \mathrm{~N} \mathrm{Na}_{2} \mathrm{~S}_{2} \mathrm{O}_{3}, \mathrm{ml}$;

$V_{0}$-consumed amount of $0.1 \mathrm{~N} \mathrm{Na}_{2} \mathrm{~S}_{2} \mathrm{O}_{3}, \mathrm{ml}$ in blank test;

$m$-weight of activated carbon, $\mathrm{g}$;

50 -volume of $0.1 \mathrm{~N}$ iodine solution, $\mathrm{ml}$;

0.0127-amount of iodine contained in $1 \mathrm{ml}$ of $0.1 \mathrm{~N}$ iodine, $\mathrm{g}$.

Porous and crystal structure determination. X-ray diffraction patterns of raw coals and activated carbon samples are recorded using a diffractometer (XRD mini Flex 600) employing with $\mathrm{Cu} \mathrm{Ka}$ radiation $(40 \mathrm{kV}, 30 \mathrm{~mA})$. The diffraction angle is selected from $5^{\circ}$ to $70^{\circ}$ with a scan rate of $5^{\circ} / \mathrm{min}$ and step size of $0.01^{\circ}$. BET surface area is measured using the Flowsorb III 2305/2310. Nitrogen adsorption is done at the temperature of $77 \mathrm{~K}$ in $\mathrm{N}_{2}$ flow with a flow rate of 53 $\mathrm{ml} / \mathrm{min}$. SEM measurement of activated carbon is performed by the JEOL JSM $7001 \mathrm{~F}$ model to show carbon micro textural structure.

\section{Results and Discussions}

\subsection{Effect of Coal Types on Porous Structure Development in Activated Carbons}

Figure 2 shows activation temperature and weight loss corresponding to the activation method and coal type. It is found that the weight loss of $\mathrm{KH}$ coal sample

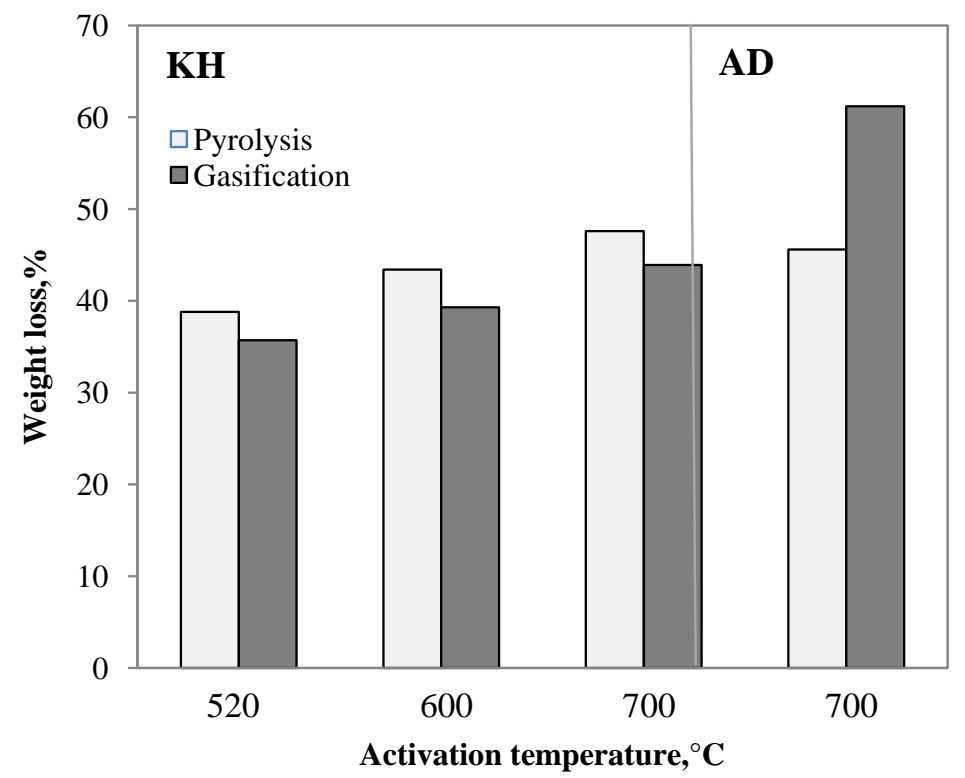

Figure 2. Weight losses depending on coal type, activation method and temperature. 
is increased gradually with increasing temperature in both cases of pyrolysis and gasification.

The AD coal sample is activated at only $700^{\circ} \mathrm{C}$ by all activation methods. Pyrolysis of $\mathrm{KH}$ and $\mathrm{AD}$ coal samples at $700^{\circ} \mathrm{C}$ give almost similar weight losses of $47.6 \%$ and $45.6 \%$, respectively. However, as can be seen in Figure 2, the increments of weight losses as increasing the gasification temperature of the $\mathrm{KH}$ sample is not so high compared to the weight losses from its pyrolysis. For the AD coal sample, the gasification gives a high weight loss of $61.2 \%$ in comparison with the weight losses from the $\mathrm{AD}$ lignite pyrolysis at $700^{\circ} \mathrm{C}$ and from gasification of $\mathrm{KH}$ coal sample at $700^{\circ} \mathrm{C}$, respectively.

Activated carbon yields and their porosities after physical activation at different temperatures are described in Table 2. As shown here, activated carbon yield decreases with increase of activation temperature in both cases of pyrolysis and gasification. Due to removal of coal volatiles and burn-off of carbons, the iodine number which represents a micropore content with the sizes of $0-2 \mathrm{~nm}$ increases with increasing the activation temperature of $\mathrm{KH}$ coal sample. It is interesting that the methylene blue number, which represents a microporosity $(>1.5$ $\mathrm{nm}$ ) and a mesoporosity (2-50 nm), is identified only for the activated carbons prepared by the activation processes of the AD lignite sample. Moreover, it can be seen that the $\mathrm{AD} 700^{\circ} \mathrm{C}-\mathrm{G}$ contains the highest amounts of micropores and mesopores formed by the steam gasification of the $\mathrm{AD}$ lignite.

BET surface area is an important value for the determination of surface capacity of adsorbent materials [17] [18] [19]. It is determined that the physical activation by steam gasification of $\mathrm{AD}$ lignite develops well a porous structure with the highest surface area of $522 \mathrm{~m}^{2} / \mathrm{g}$ which is three times larger than that (155 $\mathrm{m}^{2} / \mathrm{g}$ ) of the activated carbon produced by pyrolysis of the same lignite. It could be concluded that coal gasification is the most suitable method to prepare a porous material from coal sample. In case of $\mathrm{KH}$ coal, BET surface area (214 $\mathrm{m}^{2} / \mathrm{g}$ ) of the $\mathrm{KH} 700^{\circ} \mathrm{C}-\mathrm{G}$ is still two times smaller than the value with the $\mathrm{AD} 700^{\circ} \mathrm{C}-\mathrm{G}$ sample perhaps due to lower reactivity of $\mathrm{KH}$ sub-bituminous coal with a steam even at high temperature.

Table 2. Obtained yields and porosities of activated carbons after physical activation at different temperatures.

\begin{tabular}{ccccc}
\hline AC code & $\begin{array}{c}\text { AC Yield, } \\
\text { wt\% }\end{array}$ & Iodine number \% & $\begin{array}{c}\text { Methylene blue number } \\
\mathrm{mg} / \mathrm{g}\end{array}$ & $\begin{array}{c}\text { BET Surface Area, } \\
\left(\mathrm{m}^{2} / \mathrm{g}\right)\end{array}$ \\
\hline $\mathrm{KH} 520^{\circ} \mathrm{C}-\mathrm{P}$ & 61.2 & 20.6 & 0 & 5.80 \\
$\mathrm{KH} 600^{\circ} \mathrm{C}-\mathrm{P}$ & 56.6 & 22.2 & 0 & 17.9 \\
$\mathrm{KH} 700^{\circ} \mathrm{C}-\mathrm{P}$ & 52.4 & 33.7 & 0 & 68.8 \\
$\mathrm{AD} 700^{\circ} \mathrm{C}-\mathrm{P}$ & 54.4 & 21.8 & 6 & 155 \\
$\mathrm{KH} 520^{\circ} \mathrm{C}-\mathrm{G}$ & 64.3 & 23.1 & 0 & - \\
$\mathrm{KH} 600^{\circ} \mathrm{C}-\mathrm{G}$ & 60.7 & 18.4 & 0 & 18.4 \\
$\mathrm{KH} 700^{\circ} \mathrm{C}-\mathrm{G}$ & 56.1 & 32.5 & 0 & 214 \\
$\mathrm{AD} 700^{\circ} \mathrm{C}-\mathrm{G}$ & 38.8 & 89.6 & 36 & 522 \\
\hline
\end{tabular}




\subsection{Characterization of Coal and Activated Carbon Samples}

Porosity analysis and weight loss obtained by the physical activation of the coal samples show that the high temperature processes influence effectively the creation of pore structure in the activated carbons. Changes in the coal samples by activation processes at $700^{\circ} \mathrm{C}$ are checked by FT-IR analysis. In Figure 3 , as the peak in the range of $3200-3550 \mathrm{~cm}^{-1}$ represents the presence of alcohols/phenols in the activated carbons, and the peak at $2926 \mathrm{~cm}^{-1}$ is corresponding to the $\mathrm{C}-\mathrm{H}$ stretching vibration of aliphatic chains. Therefore, it is revealed that the thermal processes of the $\mathrm{KH}$ coal sample cracked some alkyl side groups; however the phenolic compounds cannot be decomposed due to condensed macromolecular structure of the sub-bituminous coal. During pyrolysis and gasification of the $\mathrm{KH}$ coal sample, aromatization and condensation of coal fragments occur, consequently the peak intensity of aromatic $\mathrm{C}-\mathrm{H}$ bending at $803 \mathrm{~cm}^{-1}$ increased, and porosity cannot be developed sufficiently compared to that from the AD sample. On the contrary, the peaks attributed to the alcohol$\mathrm{ic} /$ phenolic - $\mathrm{OH}$ functional groups are almost disappeared by the thermal treatments of the $\mathrm{AD}$ lignite sample at $700^{\circ} \mathrm{C}$. This result is also confirmed by very small absorbance of the peaks at $1158 \mathrm{~cm}^{-1}$, which is attributed to C-O bending of alcohol/phenolic compounds, in the $\mathrm{AD}$ activated carbons.

For both coal samples, the peak at $1607 \mathrm{~cm}^{-1}$ attributed to $\mathrm{C}=\mathrm{O}$ carbonyl group is disappeared by the thermal activation treatments. It might be related to hydrogenation similar chances in hydrogen-rich atmosphere during coal cracking and gasification reaction for the $\mathrm{KH}$ sub-bituminous coal and $\mathrm{AD}$ lignite. The small peaks at $2324-2328 \mathrm{~cm}^{-1}$ are observed in the samples probably due to adsorbed carbon dioxide in measurement atmosphere.

XRD patterns for both series of samples indicate gradual changes according to the progress in activation. Figure 4 shows the diffraction profiles of the raw coal samples and activated carbons prepared by pyrolysis and gasification at $700^{\circ} \mathrm{C}$.
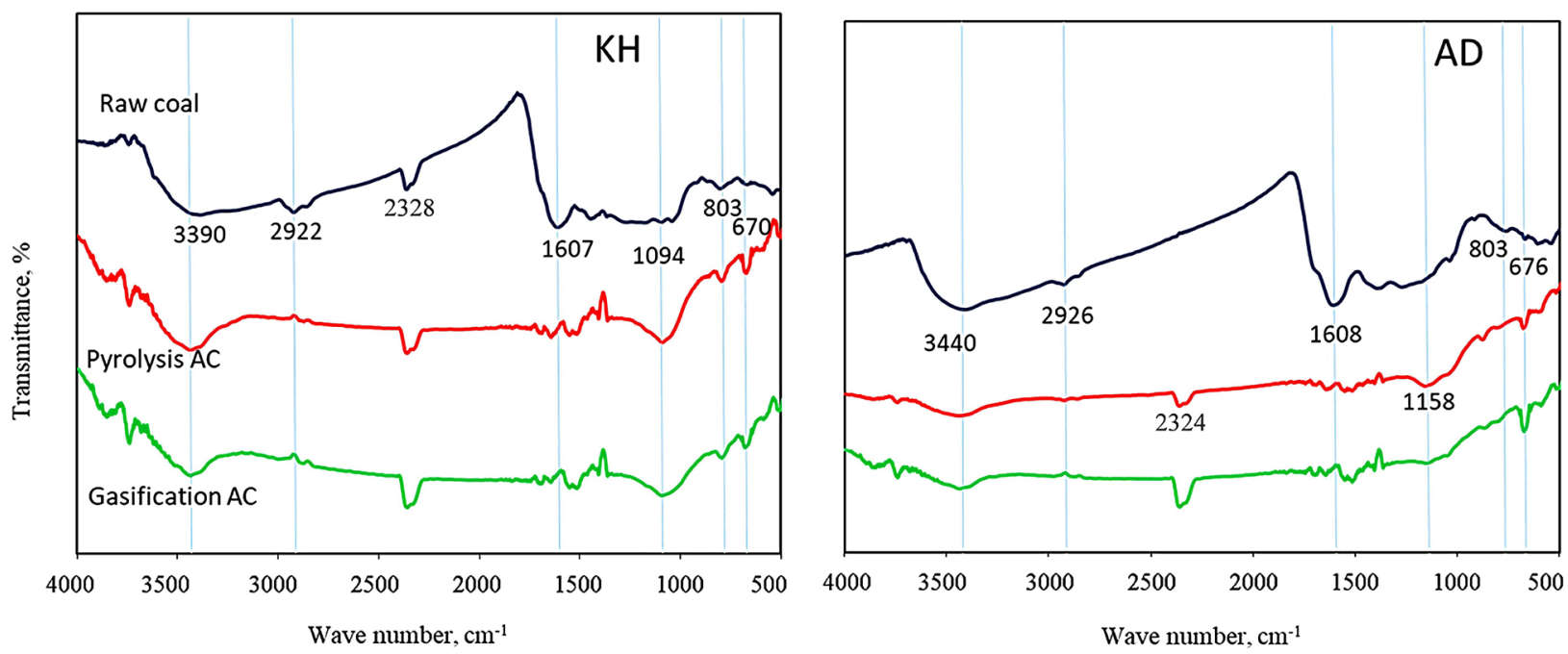

Figure 3. FT-IR spectra of raw coals, pyrolysis and gasification AC-s prepared from KH sub-bituminous coal and AD lignite at $700^{\circ} \mathrm{C}$. 


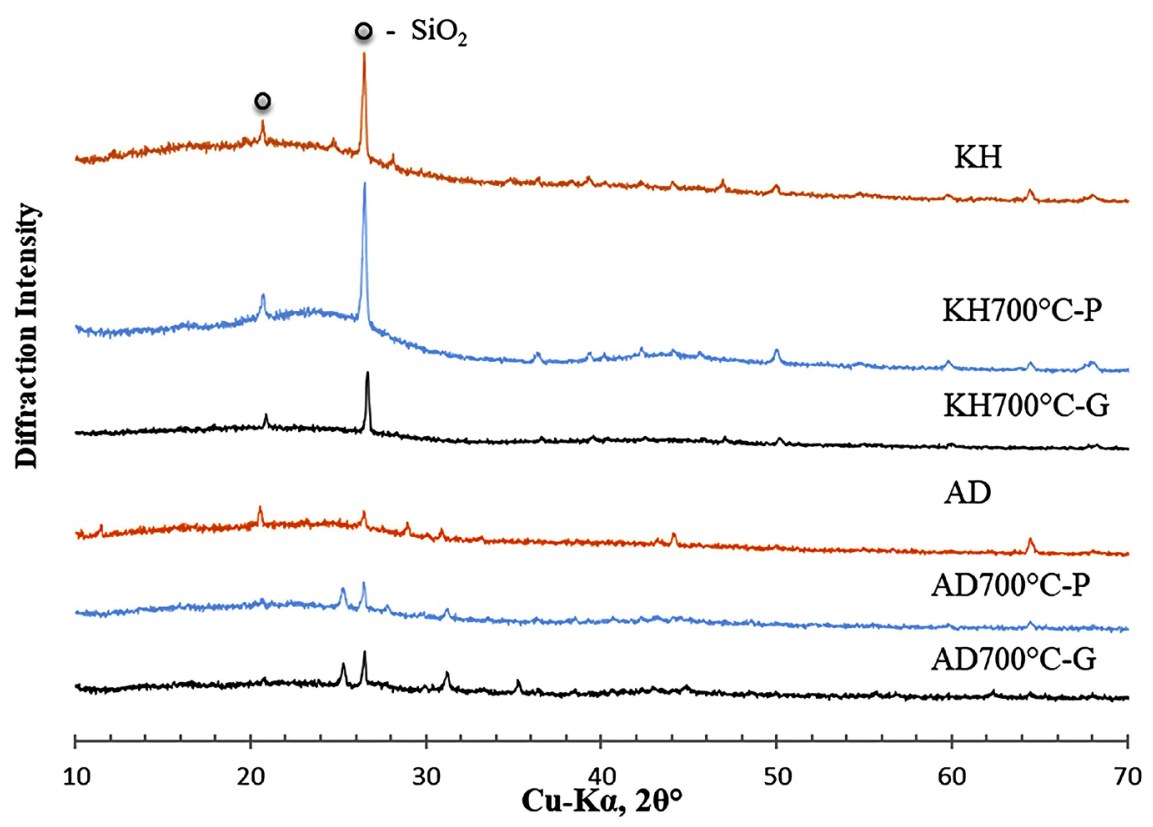

Figure 4. XRD profiles of the raw coal samples and activated carbons prepared by pyrolysis and gasification at $700^{\circ} \mathrm{C}$.

In Figure 4, for both series of the samples, broad peak around $2 \theta=20^{\circ}-25^{\circ}$ corresponds to (002) reflection of carbon because of the stacking structure of coal aromatic structure. Broadening of the 002 peak can be interpreted in terms of non-crystallinity of carbon structure [20] [21]. Burn-off of coal samples by the thermal treatments has been corresponded to decrease of the 002 carbon peak intensity, as shown in Figure 4. As shown in Table 1, ash contents of the $\mathrm{KH}$ and $\mathrm{AD}$ coal samples are $16.7 \mathrm{wt} \%$ and $9.9 \mathrm{wt} \%$ (on dry base), respectively. These data suggest that the feed coal samples contain their inherent minerals species. Moreover, it can be seen in Figure 4, that the samples contain mainly quartz species before and after physical activation. In case of $\mathrm{KH}$ coal sample, there are several unknown peaks of its inherent minerals, and the peaks are almost not changed after the treatments. However, some changes are observed after thermal treatments of the $\mathrm{AD}$ coal exhibiting decomposition of the inherent minerals during its activation processes.

SEM images with the same zooming scale of the activated carbons which are prepared by pyrolysis and gasification at $700^{\circ} \mathrm{C}$ are shown in Figure 5 and Figure 6. As shown in Figure 5(A), Figure 5(B), although there are some cracks and crevices in external surface of the $\mathrm{KH} 700^{\circ} \mathrm{C}-\mathrm{P}$ and the $\mathrm{KH} 700^{\circ} \mathrm{C}-\mathrm{G}$, it seems that holes and porous structure are not observed in micrographs of the activated carbons prepared from $\mathrm{KH}$ sub-bituminous coal. However, as shown in Figure 6(A), Figure 6(B), the holes and porous structure are described clearly on external surface of the $\mathrm{AD} 700^{\circ} \mathrm{C}-\mathrm{G}$ sample.

It can be concluded from SEM images taken during tests performed at the physical activations at $700^{\circ} \mathrm{C}$ that porous structure is well developed because of the large removal of volatiles and carbons and the high reactivity of the $\mathrm{AD}$ lignite 


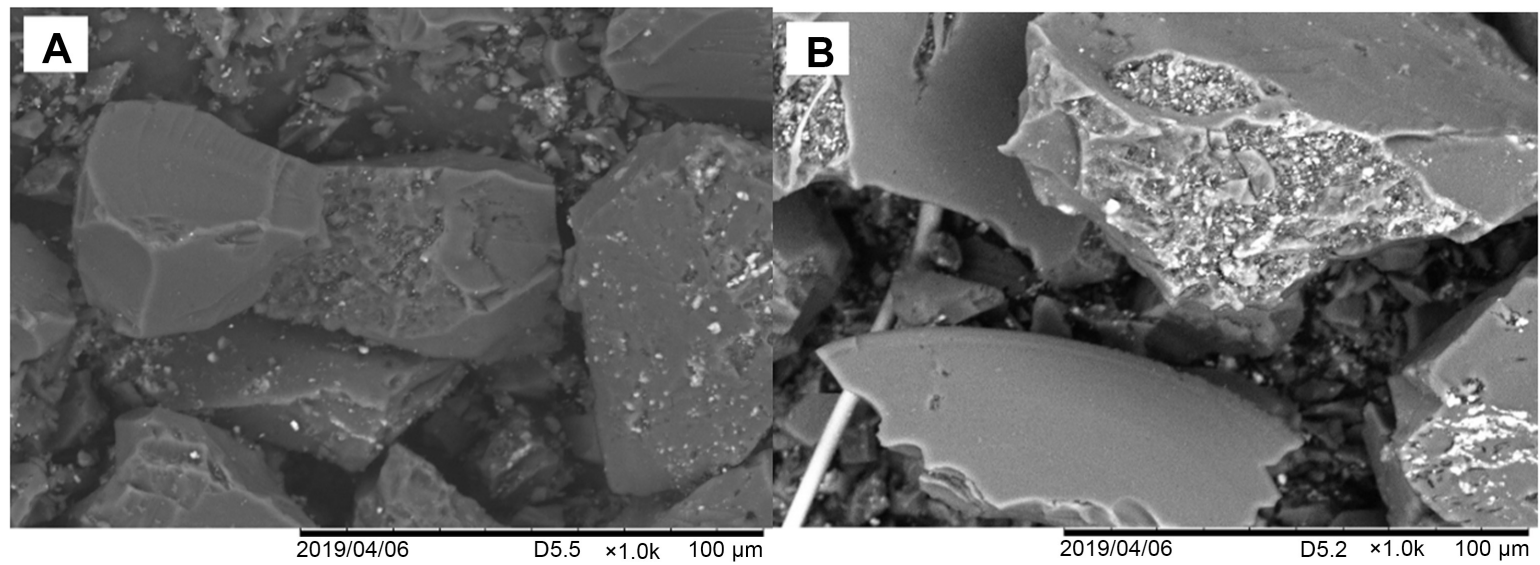

Figure 5. SEM images of the activated carbons prepared from $\mathrm{KH}$ sub-bituminous coal. (A) Activated carbon-KH700 ${ }^{\circ} \mathrm{C}-\mathrm{P}$; (B) Activated carbon- $\mathrm{KH} 700^{\circ} \mathrm{C}-\mathrm{G}$.

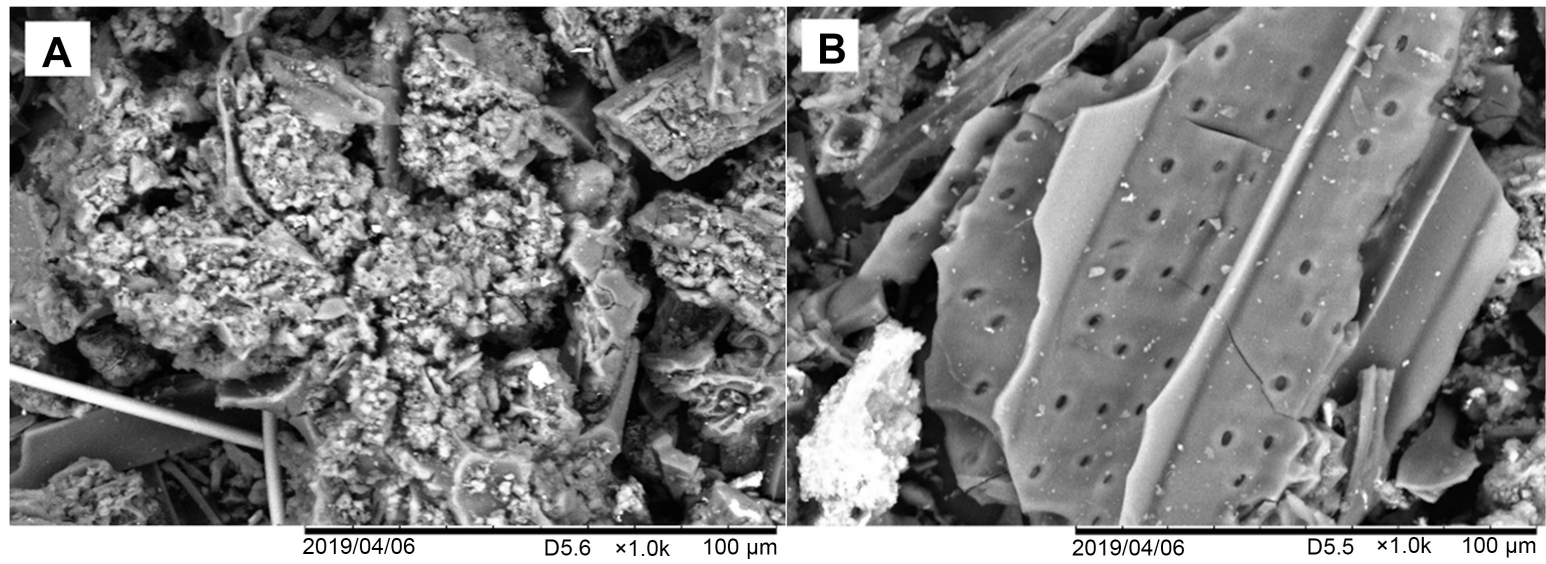

Figure 6. SEM images of the activated carbons prepared from AD lignite. (A) Activated carbon-AD700 ${ }^{\circ} \mathrm{C}-\mathrm{P}$; (B) Activated carbon- $\mathrm{AD} 700^{\circ} \mathrm{C}-\mathrm{G}$.

with a steam. Moreover, pyrolysis and gasification of $\mathrm{KH}$ sub-bituminous coal cannot occur through whole mass of coal aromatic condensed macromolecule skeleton, nevertheless coal small parts joined with the macromolecule by weak and single bonds are cracked during its activation.

\section{Conclusions}

Activation process of coal pyrolysis has a different tendency on porosity development for the $\mathrm{KH}$ sub-bituminous coal and the AD lignite samples. As increasing pyrolysis temperature, the yield of activated carbons from the $\mathrm{KH}$ coal is lowered, and the amount of micropores increases gradually; however there is no development of mesopores by the pyrolysis. The KH sub-bituminous coal has a small loss during physical activation due to difficulty and inactivity of its macrostructure decomposition; the smaller porosity is developed in the resulting carbons.

It is identified that the physical activation by gasification of AD lignite develops well a porous structure with the highest surface area of $522 \mathrm{~m}^{2} / \mathrm{g}$ which is 
three times larger than that $\left(155 \mathrm{~m}^{2} / \mathrm{g}\right)$ of the activated carbon produced by pyrolysis of the same lignite. The IR and SEM analysis confirm a difference in chemical and structural changes between the raw coals and corresponding carbon samples.

\section{Conflicts of Interest}

The authors declare no conflicts of interest regarding the publication of this paper.

\section{References}

[1] Lee, J., Kim, J. and Hyeon, T. (2006) Recent Progress in the Synthesis of Porous Carbon Materials. Advanced Materials, 18, 2073-2094.

https://doi.org/10.1002/adma.200501576

[2] Zou, Y. and Han, B.-X. (2001) High-Surface-Area Activated Carbon from Chinese Coal. Energy \& Fuels, 15, 1383-1386. https://doi.org/10.1021/ef0002851

[3] Fujimoto Kaoru, N.I. (1988) Activation of Coal with $\mathrm{CO}_{2}$ and Its Utilization. Proceeding of the 25 th Coal Science Conference, 20-25.

[4] Teng, H., Yeh, T.-S. and Hsu, L.-Y. (1998) Preparation of Activated Carbon from Sub-Bituminous Coal with Phosphoric Acid Activation. PII: S0008-6223(98) 00127-4, 1387-1395. https://doi.org/10.1016/S0008-6223(98)00127-4

[5] Byambajav, E., Paysepar, H., Nazari, L. and Xu, C. (2018) Co-Pyrolysis of Lignin and Low Rank Coal for the Production of Aromatic Oils. Fuel Processing Technology, 181, 1-7. https://doi.org/10.1016/j.fuproc.2018.09.008

[6] Naoto, T., Yuuki, M., Enkhsaruul, B., Yuu, H., Takemitsu, K. and Yasuo, O. (2017) Steam Gasification of Low-Rank Coals with Ion-Exchanged Sodium Catalysts Prepared Using Natural Soda Ash. Energy \& Fuels, 31, 2565-2571.

https://doi.org/10.1021/acs.energyfuels.6b02905

[7] Byambajav, E., Hachiyama, Y., Kudo, S., Norinaga, K. and Hayashi, J. (2016) Kinetics and Mechanism of $\mathrm{CO}_{2}$ Gasification of Chars from Mongolian 11 Lignites. Energy \& Fuels, 30, 1636-1646. https://doi.org/10.1021/acs.energyfuels.5b02262

[8] Byambajav, E. and Ohtsuka, Y. (2004) Novel Utilization of Mesoporous Molecular Sieves as Supports of Metal Catalysts for Hydrocracking of Asphaltene. In: Heavy Hydrocarbon Resources, Chapter 15, Springer, Berlin, 205. https://doi.org/10.1021/bk-2005-0895.ch015

[9] Byambajav, E. and Ohtsuka, Y. (2003) Cracking Behavior of Asphaltene in the Presence of Iron Catalysts Supported on Mesoporous Molecular Sieve with Different Pore Diameters. Fuel, 82, 1571. https://doi.org/10.1016/S0016-2361(03)00094-2

[10] Reimerink, W.M.T.M. (1999) The Use of Activated Carbon as Catalyst and Catalyst Carrier in Industrial Applications. Studies in Surface Science and Catalysis, 120A, 751-769. https://doi.org/10.1016/S0167-2991(99)80571-0

[11] Dabrowski, A. (2001) Adsorption from Theory to Practice. Advances in Colloid and Interface Science, 93, 135-224. https://doi.org/10.1016/S0001-8686(00)00082-8

[12] Ahmadpour, A. and Do, D.D. (1996) The Preparation of Active Carbons from Coal by Chemical and Physical Activation. Carbon, 34, 471-479.

https://doi.org/10.1016/0008-6223(95)00204-9

[13] Walker, P.L., Shelef, M. and Anderson, R.A. (1968) Catalysis of Carbon Gasification. In: Walker Jr., P.L., Ed., Chemistry and Physics of Carbon, Volume 4, Marcel 
Dekker, New York, 287-383.

[14] Verheyen, V., Rathbone, R., Jagtoyen, M. and Derbyshire, F. (1995) Activated Extrudates by Oxidation and $\mathrm{KOH}$ Activation of Sub-Bituminous Coal. Carbon, 33 , 763-772. https://doi.org/10.1016/0008-6223(95)00010-B

[15] Tsai, W.T., Chang, C.Y., Wang, S.Y., Chang, C.F., Chien, S.F. and Sun, H.F. (2001) Preparation of Activated Carbons from Corn Cob Catalyzed by Potassium Salts and Subsequent Gasification with $\mathrm{CO}_{2}$. Bioresource Technology, 78, 203-208. https://doi.org/10.1016/S0960-8524(00)00111-5

[16] Shrestha, R.M. (2016) Effect of Preparation Parameters on Methylene Blue Number of Activated Carbons Prepared from a Locally Available Material. Journal of the Institute of Engineering, 12, 169-174. https://doi.org/10.3126/jie.v12i1.16900

[17] Hidayu, A.R., Mohamad, N.F., Matali, S. and Sharifah, A.S.A.K. (2013) Characterization of Activated Carbon Prepared from Oil Palm Empty Fruit Bunch Using BET and FT-IR Techniques. Procedia Engineering, 68, 379-384.

https://doi.org/10.1016/j.proeng.2013.12.195

[18] Gomez-Serrano, V., Pastor-Villegas, J., Perez-Florindo, A., Duran-Valle, C. and Valenzuela-Calahorro, C. (1995) FT-IR Study of Rockrose and of Char and Activated Carbon. Journal of Analytical and Applied Pyrolysis, 36, 71-80.

https://doi.org/10.1016/0165-2370(95)00921-3

[19] Saka, C. (2012) BET, TG-DTG, FT-IR, SEM, Iodine Number Analysis and Preparation of Activated Carbon from Acorn Shell by Chemical Activation with $\mathrm{ZnCl}_{2}$. Journal of Analytical and Applied Pyrolysis, 95, 21-24.

https://doi.org/10.1016/j.jaap.2011.12.020

[20] Hung, Y.T., Lo, H.H., Wang, L.K., Taricska, J.R. and Li, K.H. (2005) Granular Activated Carbon Adsorption. In: Wang, L.K., Hung, Y.T. and Shammas, N.K., Eds., Handbook of Environmental Engineering, Volume 3, Humana Press, Totowa, NJ, 573-634. https://doi.org/10.1385/1-59259-820-x:573

[21] Yoshizawa, N., Maruyama, K., Yamada, Y. and Zielinska-Blajet, M. (2000) XRD Evaluation of $\mathrm{CO}_{2}$ Activation Process of Coal- and Coconut Shell-Based Carbons. Fuel, 79, 1461-1466. https://doi.org/10.1016/S0016-2361(00)00011-9 